\title{
Comparative analysis of diagnostic scales of acute appendicitis: Alvarado, RIPASA and AIR
}

\author{
Análisis comparativo de escalas diagnósticas de apendicitis aguda: Alvarado, RIPASA y AIR \\ Martín A. Bolívar-Rodríguez ${ }^{*}$, Benny A. Osuna-Wong ${ }^{1}$, Ana B. Calderón-Alvarado', Jaime Matus-Rojas ${ }^{1}$, \\ Edgar Dehesa-López ${ }^{3}$ and Felipe de Jesús Peraza-Garay ${ }^{3}$ \\ ${ }^{1}$ Department of General Surgery; ${ }^{2}$ Department of Research; ${ }^{3}$ Department of Statistics. Center of Health Sciences Research and Teaching, \\ Universidad Autónoma de Sinaloa, Culiacán, Sin. Mexico
}

\begin{abstract}
Introduction: Acute appendicitis is the most common surgical disease in emergency surgery, however, it remains a diagnostic problem and represents a challenge despite the experience and the different clinical and paraclinical diagnostic methods. Objective: To evaluate in a comparative way the scale of Alvarado, AIR and RIPASA to determine which one is best as a diagnostic test of acute appendicitis in our population in order to arrive to an accurate diagnosis in the shortest possible time and cost. Method: Observational, prospective, transversal and comparative study of 137 patients to whom the scale of Alvarado, AIR and RIPASA was applied, who entered the emergency service of the Civil Hospital of Culiacán (México) with abdominal pain syndrome suggestive of acute appendicitis. Results: The Alvarado scale presented sensitivity $97.2 \%$ and specificity of $27.6 \%$. AIR presented sensitivity of $81.9 \%$ and specificity of $89.5 \%$. RIPASA showed the same results as Alvarado. All tests showed diagnostic accuracy above $80 \%$. Conclusions: Alvarado and RIPASA presented good sensitivity, however, AIR is more specific, and has better accuracy for the diagnosis of acute appendicitis, making a better screening and thus reducing unnecessary surgeries. Therefore, it is recommended to use more AIR than Alvarado and RIPASA.
\end{abstract}

KEY WORDS: Appendicitis. Diagnosis. Alvarado. RIPASA. AIR.

\section{Resumen}

Introducción: La apendicitis aguda es la enfermedad quirúrgica más común en cirugía de urgencia; sin embargo, sigue siendo un problema diagnóstico y representa un reto a pesar de la experiencia y los diferentes métodos de diagnóstico clínicos y paraclínicos. Objetivo: Evaluar en forma comparativa las escalas de Alvarado, AIR y RIPASA para determinar cuál es superior como prueba diagnóstica de apendicitis aguda en nuestra población, llegando a un diagnóstico preciso en el menor tiempo y costo posibles. Método: Estudio observacional, prospectivo, transversal y comparativo de 137 pacientes a quienes se aplicó las escalas de Alvarado, AIR y RIPASA, que ingresaron al servicio de urgencias del Hospital Civil de Culiacán (México) con síndrome doloroso abdominal sugestivo de apendicitis aguda. Resultados: La escala de Alvarado presentó una sensibilidad del $97.2 \%$ y una especificidad del $27.6 \%$. AlR tuvo una sensibilidad del $81.9 \%$ y una especificidad del 89.5\%. RIPASA arrojó los mismos resultados que Alvarado. Todas las pruebas tuvieron una exactitud diagnóstica por arriba del $80 \%$. Conclusiones: Alvarado y RIPASA presentaron buena sensibilidad, mientras que AIR es más específica y tiene mayor exactitud diagnóstica de apendicitis aguda, realizando un mejor tamizaje y permitiendo disminuir las cirugías innecesarias, por lo que se recomienda usar más AIR que Alvarado y RIPASA.

PALABRAS CLAVE: Apendicitis. Diagnóstico. Alvarado. RIPASA. AIR.

\author{
Correspondence: \\ *Martín A. Bolívar-Rodríguez \\ Eustaquio Buelna 91, \\ Col. Gabriel Leyva \\ C.P. 80030 Culiacán, Sin., México \\ E-mail: bolivarmartin64@ hotmail.com
}

Date of reception: 02-02-2018

Date of acceptance: $16-04-2018$

DOI: 10.24875/CIRUE.M18000024
Cir Cir. 2018;86:151-155

Contents available at PubMed www.cirugiaycirujanos.com 


\section{Introduction}

Acute appendicitis is the surgical condition that most often causes hospitalization and emergency surgery; however, even after such a long time elapsed since its first description, sometimes it remains a diagnostic problem and represents a challenge for all doctors who treat patients with symptoms suggestive of this pathological process, despite the experience and the different clinical and paraclinical diagnostic methods.

Appendectomy is currently the most common emergency surgical procedure in the world. The risk of developing acute appendicitis throughout life is estimated at approximately $7 \%$. Its incidence is 11 cases per 10,000 people per year in developed countries ${ }^{1}$. In the USA, 250,000 cases of appendicitis are reported annually, representing one million patient-hospital days per year ${ }^{2}$. In our population, estimates indicate that one in every $15-20$ people will develop acute appendicitis at some point in life, with a reported incidence of $1.5-1.9$ cases per 1000 population ${ }^{3}$.

Incorrect or late diagnosis increases the risk of complications, and the rate of appendicitis misdiagnosis was thus reported to range between 15 and $25 \%$, which is considered acceptable to reduce the incidence of complications ${ }^{4}$. However, in recent years, the frequency of negative appendectomies has been decreasing in a sustained manner in association with the use of diagnostic imaging studies. "Now there is clear evidence that (previously used ranges) should not be considered acceptable anymore" ${ }^{\prime \prime}$. However, in our setting, routine medical history and physical examination continue to be the most practical diagnostic modalities ${ }^{6}$. Today, a number of authors claim that acute appendicitis diagnosis continues to be clinical, as Rebollar et al. ${ }^{7}$ refer: "a weII-structured medical history, as well as a good physical examination, provide the diagnosis in most cases".

Despite being a common condition, it remains a difficult-to-establish diagnosis, especially in the population groups of young people, the elderly and women of childbearing age, in whom various inflammatory conditions of the gynecological and genitourinary tract can exhibit signs and symptoms that are similar to those of acute appendicitis. A delay in the performance of appendectomy in order to improve diagnostic accuracy increases the risk of appendicular perforation and sepsis, as well as morbidity and mortality ${ }^{8}$.

Currently, there are numerous tools that can be used in the assessment of patients with suspected appendicitis. How these tools are combined in clinical practice
Table 1. The Alvarado Scale

\begin{tabular}{|c|c|}
\hline Alvarado Scale & Points \\
\hline \multicolumn{2}{|l|}{ Symptoms } \\
\hline Migratory pain & 1 \\
\hline Anorexia/ketonuria & 1 \\
\hline Nausea/vomiting & 1 \\
\hline \multicolumn{2}{|l|}{ Signs } \\
\hline Right iliac fossa pain & 2 \\
\hline Rebound & 1 \\
\hline Temperature $>37.3^{\circ} \mathrm{C}$ & 1 \\
\hline \multicolumn{2}{|l|}{ Laboratory } \\
\hline Leukocytosis > 100,000 cells $/ \mathrm{mm}^{3}$ & 2 \\
\hline Neutrophilia $>75 \%$ & 1 \\
\hline \multicolumn{2}{|c|}{$\begin{array}{l}\text { Low risk: 0-4 points. There is a very low probability of appendicitis, since very rare } \\
\text { cases have occurred with less than } 4 \text { points. } \\
\text { Intermediate risk: } 5-6 \text { points. The patient presents with probable appendicitis } \\
\text { and serial evaluations, both clinical and laboratory, as well as some imaging } \\
\text { studies (ultrasonography, computed tomography) will be required. } \\
\text { High risk: } 7 \text { points or more. The patient requires surgery, since he/she is considered to } \\
\text { be suffering from acute appendicitis. }\end{array}$} \\
\hline
\end{tabular}

largely depends on the framework, availability of resources and clinical objectives. For example, in rural areas of Kenya, clinical evaluation remains the cornerstone of diagnosis for everybody. In Washington, the diagnostic goals vary depending on the patient: for children, minimizing ionizing radiation exposure can mitigate the desire for more diagnostic information; for women aged 18 to 35 years, specifically ruling out non-appendicular disease can be a priority; for elderly patients, in whom radiation is less risky, the clarity and the quantity of information provided by computed tomography can justify its systematic use ${ }^{9}$.

In consequence, several scales (Alvarado, RIPASA and AIR) include acute appendicitis classic signs and symptoms plus laboratory tests.

The Alvarado scale (Table 1) is the most widely known and the one that until a few years ago showed the best performance in validation studies ${ }^{10}$. It was developed in 1986 by Dr. Alfredo Alvarado ${ }^{11}$. The Appendicitis Inflammatory Response (AIR) scale (Table 2) is a scoring system, created in Sweden in 2008, developed by Andersson and Andersson ${ }^{12}$. More recently, the RIPASA scale (Table 3 ) has been published in the Raja Isteri Pengiran Anak Saleha Hospital (RIPAS), by Chong, et al. ${ }^{13}$. Since this scale was developed in Asia in 2010, its applicability and effectiveness in other populations is still under study.

\section{Method}

A prospective, cross-sectional, comparative, observational study was carried out in 137 patients who were admitted to the Hospital Civil de Culiacán emergency 
Table 2. The AIR Scale

\begin{tabular}{|c|c|}
\hline Air Scale & Points \\
\hline \multicolumn{2}{|l|}{ Symptoms } \\
\hline Right iliac fossa pain & 1 \\
\hline Vomiting & 1 \\
\hline \multicolumn{2}{|c|}{ Signs } \\
\hline \multicolumn{2}{|c|}{ Rebound/right iliac fossa muscular resistance } \\
\hline Mild & 1 \\
\hline Moderate & 2 \\
\hline Severe & 3 \\
\hline Temperature $>38.5^{\circ} \mathrm{C}$ & 1 \\
\hline \multicolumn{2}{|l|}{ Laboratory } \\
\hline $100,000-14,900$ cells $/ \mathrm{mm}^{3}$ & 1 \\
\hline$\geq 15,000$ cells $/ \mathrm{mm}^{3}$ & 2 \\
\hline \multicolumn{2}{|l|}{ Leukocytosis } \\
\hline \multicolumn{2}{|l|}{ Neutrophilia } \\
\hline $70-84 \%$ & 1 \\
\hline$\geq 85 \%$ & 2 \\
\hline \multicolumn{2}{|l|}{ C-reactive protein } \\
\hline $10-49 \mathrm{~g} / \mathrm{L}$ & 1 \\
\hline$\geq 50 \mathrm{~g} / \mathrm{L}$ & 2 \\
\hline \multicolumn{2}{|c|}{$\begin{array}{l}\text { Low probability: 0-4 points. Outpatient follow-up if there is no general status compromise. } \\
\text { Undetermined: 5-8 points. In-hospital active observation with re-evaluation of the } \\
\text { score and diagnostic imaging studies or laparoscopy according to the protocols of the } \\
\text { hospital unit. } \\
\text { High probability: } 9-12 \text { points. Surgical exploration. }\end{array}$} \\
\hline
\end{tabular}

Table 3. The RIPASA Scale

\begin{tabular}{|c|c|}
\hline RIPASA Scale & Points \\
\hline \multicolumn{2}{|l|}{ Data } \\
\hline Male & 1 \\
\hline Female & 0.5 \\
\hline$<39.9$ years & 1 \\
\hline$>40$ years & 0.5 \\
\hline Foreigner & 1 \\
\hline \multicolumn{2}{|l|}{ Symptoms } \\
\hline Right iliac fossa pain & 0.5 \\
\hline Nausea/vomiting & 1 \\
\hline Migratory pain & 0.5 \\
\hline Anorexia & 1 \\
\hline Symptoms < 48 hours & 1 \\
\hline Symptoms > 48 hours & 0.5 \\
\hline \multicolumn{2}{|l|}{ Signs } \\
\hline Right iliac fossa tenderness & 1 \\
\hline Voluntary muscular resistance & 2 \\
\hline Rebound & 1 \\
\hline Rovsing & 2 \\
\hline Fever $>27$ and $<39^{\circ} \mathrm{C}$ & 1 \\
\hline \multicolumn{2}{|l|}{ Laboratory } \\
\hline Leukocytosis & 1 \\
\hline Negative urinalysis & 1 \\
\hline
\end{tabular}

Unlikely: less than 5.0 points. Observation of the patient in temporary hospitalization and reassessment in 1 to 2 hours. If the score decreases, discharge; if it increases, treat accordingly.

Low probability: 5.0-7.0 points. Observation in temporary hospitalization and reassess in 1 to 2 hours, or perform imaging study to rule out acute appendicitis.

High probability: 7.5-11.0 points. Consultation with surgery department and admission.

Reassess in 1 to 2 hours. If it remains high, prepare the patient for appendectomy. In women, suggest performing ultrasonography to rule out gynecological cause. Acute appendicitis diagnosis: more than 12 points. Refer to surgery department for appendectomy. department with abdominal pain syndrome suggestive of acute appendicitis and to whom the Alvarado, AIR and RIPASA scales were applied.

\section{Inclusion criteria}

- Patients admitted to the emergency department with abdominal pain suggestive of acute appendicitis.

- Both genders.

- Age between 15 and 70 years.

- Informed consent signature.

\section{Exclusion criteria}

- Known cause of abdominal pain other than acute appendicitis.

- Patients who develop right iliac fossa pain after admission.

\section{Censoring criteria}

- Incomplete medical record.

- Voluntary discharge prior to completing the diagnostic protocol.

\section{Appendicitis diagnostic confirmation}

Ratification of the acute appendicitis diagnosis by histopathological study (reference method).

\section{Statistical analysis}

Statistical analysis was carried out with a sample size calculation for a sensitivity of $90 \%$ and specificity of $80 \%$, with an accuracy of $10 \%$ and a prevalence of $50 \%$, with a calculated $\mathrm{N}$ of 125 patients.

Data were analyzed using the statistical package for the social sciences (SPSS), version 20.

Descriptive statistics were calculated with measures of central tendency for general data, and diagnostic test analysis (sensitivity, specificity, predictive values, diagnostic accuracy) to assess each scale.

\section{Results}

The research was conducted in a total sample of 137 patients, with three study groups being formed, which were assigned the Alvarado group, RIPASA group and AIR group names, where all the patients were included, and the results compared with the reference method, namely, histopathological analysis. 
The Alvarado group was composed of 137 patients to whom the diagnostic scale was applied, with a total of $100(72.99 \%)$ patients being found to be at high risk, among whom histopathological findings were positive in $84(61.3 \%)$ and negative in $16(11.67 \%)$. There were 30 subjects $(21.89 \%)$ who were classified at intermediate risk, among which histopathological findings were positive in 20 (14.5\%) and negative in $10(7.29 \%)$; and there were seven patients $(5.10 \%)$ classified at low risk, in whom histopathological findings were positive in $4(2.91 \%)$ and negative in $3(2.18 \%)$. When all data were pooled, $105(76.64 \%)$ true positives, 21 patients $(15.32 \%)$ with positive scale and negative biopsy, $8(5.83 \%)$ true negatives and 3 patients $(2.18 \%)$ with negative scale and positive biopsy were obtained. Thus, this diagnostic scale shows a sensitivity of $97.2 \%$, specificity of $27.6 \%$, a positive predictive value of $83.3 \%$, a negative predictive value of $72.7 \%$ and a diagnostic accuracy of $82.5 \%$.

The RIPASA group consisted of 137 patients to whom the diagnostic scale was applied, with a total of 68 patients (49.63\%) being found with high probability, among whom histopathological findings were positive in $53(38.68 \%)$ and negative in $15(10.94 \%)$. There were nine patients $(6.56 \%)$ with low probability, among whom histopathological findings were positive in $2(1.45 \%)$ and negative in 7 (5.10\%). Among the 58 patients $(42.33 \%)$ in the acute appendicitis diagnosis category, the histopathological study tested positive in 52 (37.95\%) and negative in $6(4.37 \%)$; and among the 2 patients in the unlikely category, $1(0.72 \%)$ had a positive histopathological result and $1(0.72 \%)$ negative. Pooling all data, there were 105 (76.64\%) true positives, $21(15.32 \%)$ patients with positive scale and negative histopathological study, $8(5.83 \%)$ true negatives and $3(2.18 \%)$ with negative scale and positive histopathological study. Thus, this diagnostic scale shows a sensitivity of $97.2 \%$, specificity of $27.6 \%$, a positive predictive value of $83.3 \%$, a negative predictive value of $72.7 \%$ and a diagnostic accuracy of $82.5 \%$.

The AIR group consisted of 137 patients, out of which 48 were eliminated because they did not comply with the parameters required for the diagnostic scale. Finally, 91 patients were included, to whom the diagnostic scale was applied, with a total of $13(9.48 \%)$ being found with high probability, among whom histopathological findings were positive in $11(8.02 \%)$ and negative in $2(1.45 \%)$. Among 24 (17.51\%) who were classified with low probability, the histopathological study tested positive in $13(9.48 \%)$ and negative in $11(8.02 \%)$; and out of $52(37.95 \%)$ with intermediate risk, the histopathological
Table 4. Diagnostic scales results

\begin{tabular}{|c|c|c|c|c|c|c|}
\hline \multicolumn{7}{|l|}{ Results } \\
\hline & Alvarado, \% & $\mathrm{Cl}, \%$ & RIPASA, \% & $\mathrm{Cl}, \%$ & AIR, \% & $\mathrm{Cl}, \%$ \\
\hline Sensitivity & 97.2 & $\begin{array}{l}92.1 \\
99.1\end{array}$ & 97.2 & $\begin{array}{l}92.1 \\
99.1\end{array}$ & 91.9 & $\begin{array}{l}71.5 \\
89.1\end{array}$ \\
\hline Specificity & 27.6 & $\begin{array}{l}14.7 \\
45.7\end{array}$ & 27.6 & $\begin{array}{l}14.7 \\
45.7\end{array}$ & 89.5 & $\begin{array}{l}68.6 \\
97.1\end{array}$ \\
\hline PPV & 83.3 & $\begin{array}{l}75.9 \\
88.8\end{array}$ & 83.3 & $\begin{array}{l}75.9 \\
88.8\end{array}$ & 96.7 & $\begin{array}{l}88.8 \\
99.1\end{array}$ \\
\hline NPV & 72.7 & $\begin{array}{l}43.4 \\
90.3\end{array}$ & 72.7 & $\begin{array}{l}43.4 \\
90.3\end{array}$ & 56.7 & $\begin{array}{l}39.2 \\
72.6\end{array}$ \\
\hline FPR & 72.4 & $\begin{array}{l}54.3 \\
85.3\end{array}$ & 72.4 & $\begin{array}{l}54.3 \\
85.3\end{array}$ & 10.5 & $\begin{array}{c}2.9 \\
31.4\end{array}$ \\
\hline FNR & 2.8 & $\begin{array}{l}0.9 \\
7.9\end{array}$ & 2.8 & $\begin{array}{l}0.9 \\
7.9\end{array}$ & 18.1 & $\begin{array}{l}10.9 \\
28.5\end{array}$ \\
\hline Accuracy & 82.5 & $\begin{array}{l}75.3 \\
87.9\end{array}$ & 82.5 & $\begin{array}{l}75.3 \\
87.9\end{array}$ & 83.5 & $\begin{array}{l}74.6 \\
89.7\end{array}$ \\
\hline
\end{tabular}

Cl: confidence interval; FNR: false negative rate; FPR: false positive rate; NPV: negative predictive value; PPV: positive predictive value.

study was positive in $46(33.57 \%)$ and negative in $6(4.37 \%)$. When all data were pooled, there were $59(64.83 \%)$ true positives, $2(2.19 \%)$ patients with positive scale and negative histopathological study, 17 (18.68\%) true negative and 13 (14.28\%) patients with negative scale and positive histopathology. Thus, this diagnostic scale shows a sensitivity of $81.9 \%$, specificity of $89.5 \%$, a positive predictive value of $96.7 \%$, a negative predictive value of $56.7 \%$, a false positive rate of $10.5 \%$, a false negative rate of $18.1 \%$ and a diagnostic accuracy of $83.5 \%$ (Table 4 ).

\section{Discussion}

As previously described, in our review, no studies comparing these three diagnostic scales were found in the world literature, but there are numerous studies comparing Alvarado and AIR, or Alvarado and RIPASA scales. Comparing our results with those available in the world literature, we find that in the studies by Andersson and Andersson ${ }^{12}$, regarding AIR and Alvarado, there is a complete contrast, but the study by Sammalkorpi et al. ${ }^{14}$ shows similarity with ours in ter$\mathrm{ms}$ of specificity, with better sensitivity for ours in the comparison between AIR and Alvarado. As for the studies carried out by Reyes-García et al..$^{15}$ in 2012, Nanjundaiah et al..$^{8}$ in 2014, and Walczak DA et al..$^{16}$ in 2015, they report results similar to those found for the RIPASA scale in the present study, with these results being shared with the world literature. 
The first study published on the subject was carried out in Sweden in 2008, with the authors, Andersson and Andersson ${ }^{12}$, obtaining a diagnostic accuracy of 93\% for advanced appendicitis and $97 \%$ for all appendicitis cases, versus $92 \%(p=0.0027)$ and $88 \%$ $(p=0.0007)$, respectively, for the Alvarado scale.

As for diagnostic accuracy, $82.5 \%$ of diagnostic precision was obtained for Alvarado and RIPASA, versus $83.5 \%$ for AIR, with similar values to those available in the literature.

Burgos-Oliveros ${ }^{17}$ conducted a study with the purpose to evaluate the differences between these scales, which included 352 patients aged 14 to 60 years diagnosed with acute appendicitis who underwent appendectomy. The RIPASA scale shows superiority versus the Alvarado scale; in our results, the Alvarado and RIPASA scales share the same diagnostic values. On the same subject, Walczak et al..$^{16}$ carried out a study that included 92 patients who underwent laparotomy under suspicion of acute appendicitis. In this work, five different scales were compared, including RIPASA and Alvarado. The authors concluded that, based on their findings, the scale systems have a limited value for the diagnosis of acute appendicitis. Most of the used systems showed high sensitivity and a positive predictive value, which allows selecting truly ill patients and decreasing unnecessary laparotomies. On the other hand, low specificity and negative predictive value were evident, which could be associated with late diagnosis and subsequent complications. These results differ from those of the rest of the literature, particularly in regards to specificity. Our positive predictive value was high for all 3 scales, with values of $83.3 \%$ for Alvarado and RIPASA, and $96.7 \%$ for AIR; negative predictive values were low.

\section{Conclusions}

In the present study, we concluded that the Alvarado scale and the RIPASA scale have a very good margin to detect truly ill patients when they exhibit high risk, with a sensitivity of $97.2 \%$, and a high positive predictive value of $83.3 \%$, with a diagnostic accuracy that reaches $82.5 \%$.

As for the AIR scale, it shows an adequate specificity of $89.5 \%$ and a sensitivity of $81.9 \%$ when it classifies patients with high probability and intermediate probability, with a positive predictive value as high as $96.7 \%$, and a diagnostic accuracy of $83.5 \%$.

However, the research for pre-surgical diagnosis of the patient with suspected acute appendicitis continues to be challenging, even after the introduction of imaging studies, which is why these tools should be selectively used. Although acute appendicitis diagnosis is considered to be relatively easy, appendicitis classic signs can sometimes be difficult to obtain, and are unequivocally present only in $50 \%$ of patients.

This study sought to determine which scale has higher accuracy as a diagnostic test, with the AIR scale obtaining more accuracy. It can be used in our population as an objective method to support decision-making in the management of patients with suspected acute appendicitis.

As for the rate of negative appendectomies, we firmly believe that we are within an acceptable range $(13.6 \%)$ and that we should focus more on the shortterm follow-up of patients under suspicion.

\section{Conflicts of interest}

The authors declare not having any conflicts of interest.

\section{References}

1. Petroianu A. Diagnosis of acute appendicitis. Int J Surg. 2012;10:115-9.

2. Craig S. Appendicitis. Medscape. (Actualizado el 21 de julio de 2014; consultado el 10 de diciembre de 2015.) Disponible en: http://emedicine. medscape.com/article/773895-overview\#a6.

3. Asociación Mexicana de Cirugía General A.C. Guía de práctica clínica apendicitis aguda. México D.F; 2014. (Consultado el 10 de diciembre de 2015.) Disponible en: https://amcg.org.mx/images/guiasclinicas/apendicitis.pdf.

4. Shogilev DJ, Duus N, Odom SR, Shapiro NI. Diagnosing appendicitis: evidence-based review of the diagnostic approach in 2014. West $\mathrm{J}$ Emerg Med. 2014;15:859-71.

5. Drake FT, Flum DR. Improvement in the diagnosis of appendicitis. Adv Surg. 2013;47:299-328.

6. Wagner J, Mckinney P, Carpenter J. Does this adult patient have appendicitis? JAMA. 1996;276:1589-94.

7. Rebollar González RC, García Álvarez J, Trejo Téllez R. Apendicitis aguda: revisión de la literatura. Rev Hosp Jua Mex. 2009;76:210-6.

8. Nanjundaiah N, Ashfaque M, Venkatesh S, Kalpana A, Priya SA. A comparative study of RIPASA score and Alvarado score in the diagnosis of appendicitis. J Clin Diagn Res. 2014;8:NC03-5.

9. Thurston Drake F, Reed Flum D. Improvement in the diagnosis of appendicitis. Adv Surg. 2013;47:299-328.

10. Ohmann C, Yang Q, Franke C. Diagnostic scores for acute appendicitis. Abdominal Pain Study Group. Eur J Surg. 1995;161:273-81.

11. Alvarado A. A practical score for the early diagnosis of acute appendicitis. Ann Emerg Med. 1986;15:557-64.

12. Andersson M, Andersson RE. The Appendicitis Inflammatory Response score: a tool for the diagnosis of acute appendicitis that outperforms the Alvarado score. World J Surg. 2008;32:1843-9.

13. Chong CF, Thien A, Mackie AJA, Tin AS, Tripathi S, Ahmad MA, et al. Comparison of RIPASA and Alvarado scores for the diagnosis of acute appendicitis. Singapore Med J. 2011;52:340-5.

14. Sammalkorpi HE, Mentula P, Leppäniemi A. A new adult appendicitis score improves diagnostic accuracy of acute appendicitis - a prospective study. BMC Gastroenterol. 2014;14:114.

15. Reyes-García N, Zaldívar-Ramírez FR, Cruz-Martínez R, Sandoval-Martínez MD, Gutiérrez-Banda CA, Athié-Gutiérrez C. Precisión diagnóstica de la escala RIPASA para el diagnóstico de apendicitis aguda: análisis comparativo con la escala de Alvarado modificada. Cir Gen. 2012;34:101-6.

16. Walczak DA, Pawelczak D, Zoltaszek A, Jaguscik R, Falek W, Czerwinska M, et al. The value of scoring systems for the diagnosis of acute appendicitis. Pol Przegl Chir. 2015;87:65-70.

17. Burgos-Oliveros HB. Comparación entre los scores de RIPASA y Alvarado en el diagnóstico de apendicitis aguda. Tesis de titulación. Universidad Privada Antenor Orrego; 2014. 